IGUSABDER, 13 (2021): 42-55

\title{
The Effect of the Coronavirus Outbreak on Childhood Vaccinations Made in Family Health Centers in Turkey*
}

\author{
Bestegül ÇORUH AKYOL ${ }^{* *}$, Muhammed Zübeyr ÜÇÜNCÜ***, \\ Gökmen ÖZCEYLAN ${ }^{* * * *}$
}

\begin{abstract}
Aim: In our country, children are routinely vaccinated against 13 diseases, free of charge, with a total of 18 doses between the ages of 0-2. In this study, New Type CoronaVirus Disease (COVID19) is targeted to identify the outbreak's impact on vaccination rates in Turkey.

Method: Our study is a simple descriptive cross-sectional study. The data of the study were evaluated retrospectively. The units who agreed to participate and share data were listed, and one of every ten units was selected randomly, and the data of eleven family Medicine Units were included in the study.

Results: The decrease in the number of outpatient clinics in April 2020 was statistically significant. Vaccination rates decreased slightly in March and April but no statistically significant difference was found.
\end{abstract}

Conclusion: In order to maintain the vaccination rates not to decrease even in pandemic cases detected in our study, especially primary health care workers will continue to work with devotion.

Keywords: Vaccine, family physician, coronavirus, vaccination programme.

\footnotetext{
Özgün Araştırma Makalesi (Original Research Article)

Geliş / Received: 25.09.2020 \& Kabul / Accepted: 23.01.2021

DOI: https://doi.org/10.38079/igusabder.800139

* This manuscript was presented as an oral presentation at the 19th International Eastern

Mediterranean Family Medicine Congress (17-20 September 2020).

${ }^{* *}$ MD, Kağıthane Family Health Center, Istanbul, Turkey, E-mail: bestegulcoruh@yahoo.com, ORCID https://orcid.org/oooo-0002-3555-683X

*** Correspondence: Assist. Prof. Dr., Istanbul Gelisim University, Istanbul, Turkey, E-mail: muhammeducuncu@gmail.com, ORCID https://orcid.org/oooo-0003-4638-1059

**** MD, Tekirdağ Çorlu Reşadiye Family Health Center, Tekirdăg, Turkey,

E-mail: gokmenozceylan@hotmail.com ORCID http://orcid.org/O000-0002-2388-4158
} 


\section{Koronavirüs Salgınının Türkiye'deki Aile Sağlığı Merkezlerinde Yapılan Çocukluk Aşılarına Etkisi}

$\ddot{O}_{z}$

Amaç: Ülkemizde çocuklara rutin olarak o-2 yaş arası toplam 18 doz olmak üzere 13 hastalığa karşı ücretsiz aşı yapılmaktadır. Bu çalışmada, Yeni Tip Koronavirüs Hastalı̆̆ı (COVID-19) salgınının Türkiye'deki aşılama oranları üzerindeki etkisinin belirlenmesi hedeflenmektedir.

Yöntem: Çalışmanın verileri geriye dönük olarak değerlendirildi. Katılmayı ve veri paylaşmayı kabul eden birimler listelenmiş ve her on üniteden biri rastgele seçilmiş 11 Aile Hekimliği Birimi’nin verileri çalışmaya dahil edilmiştir.

Bulgular: 2020 Nisan ayında poliklinik sayısındaki düşüş istatistiksel olarak anlamlıydı. Aşılama oranları Mart ve Nisan aylarında bir miktar azalmış ancak istatistiksel olarak anlamlı bir fark bulunmamıştır.

Sonuç: Çalışmada tespit edilen pandemi vakalarında bile aşılama oranlarının düşmemesinin devamı için özellikle birinci basamak sağlık çalışanları özveri ile çalışmalarını sürdürecektir.

Anahtar Kelimeler: Aşı, aile hekimliği, koronavirüs, aşılama programı.

\section{Introduction}

In a letter that she wrote to her country in 1721, the wife of the British Ambassador, Lady Mary Montagu, astonished that there was a "thing called vaccine" (variolation method) was applied against smallpox in Istanbul. This letter is the oldest document reached for vaccine production ${ }^{1}$. Today, every country has its national vaccination system. Preventing disease in the Global World always costs less than treating it. Vaccines are one of the most important inventions regarding health in today's world.

Immunization services are one of the lowest cost health investments and are estimated to prevent 2 to 3 million deaths each year ${ }^{2}$. Vaccination services in our country are mainly carried out in primary health care institutions ${ }^{3}$. Since the beginning of the first vaccine production and application in the Ottoman Empire, vaccine logistics, implementation, and disease prevention are carried out by the state free of charge in our country ${ }^{1}$. Today in Turkey, they are applied by Family Physicians and Family Health Center staff through Turkish Republic Ministry of Health Decision Support Systems. With the population- 
based system, babies and children who are under-follow up are invited to family health centers according to the vaccine schedule via an appointment. Here, the child's development is examined with height-weight measurements, and physical examination is performed, and the vaccine is administered unless the assessed person has a contraindicated medical condition for the vaccine. In our country, children are routinely vaccinated against 13 diseases, free of charge, with a total of 18 doses between the ages of o-2. However, Rotavirus, Type B Meningitis, Influenza virus, and Human Papillomavirus vaccines, which are not included in the ministry vaccination program, can be obtained from pharmacies at the request of families and provided by the physician integration to the existing vaccination calendar in health institutions. Family physicians and family health workers are obliged to perform vaccination and child follow-ups in the monthly planned vaccination program. If there is a contraindicated condition, they can delay this vaccine. For each vaccine that cannot be administered in any way, they should document why this vaccine is not given. If there is a rejection of the vaccine, they should submit this to the Ministry with a document. The 2017 data of the reports published by the Strategic Advisory Group on vaccines to achieve global vaccination targets is the highest number ever reported. However, according to World Health Organization (WHO) data of 2018, major measles, diphtheria, and poliovirus outbreaks resulted in death in many parts of the world, have been reported 4 .

Diseases have always been a threat to humanity. Worldwide 4,338,658 cases and 297,119 deaths have been reported for New Type CoronaVirus Disease (COVID-19), which was declared as a pandemic at the end of the first half of May5. The impact status of the outbreak varies by region. While most countries are still at an early stage, in some countries, the second wave clinics have already started to appear. This pandemic once again enabled us to share the importance of vaccination with the community. Currently, multiple centers of different countries are searching for a vaccine against coronavirus that threatens all humanity with death. On the other hand, healthcare professionals continue to try to protect all humanity from new outbreaks secondary to pandemics. Because, when vaccination services are interrupted, a new increase in outbreaks for vaccine-preventable diseases is concerned. However, some families in Turkey do not want to bring their children to routine vaccination administrations, mainly because of the pandemic; the vast majority of families bring their children to family health centers 
without hesitation when they hear the necessary explanation, especially the fact that new outbreaks may develop in the future that can be life-threatening. If ever, in 2020, vaccination rates decrease, especially due to COVID-19, the delay or suspension of the planned vaccination activities will cause growing concerns about another outbreak, which, unfortunately, may become real in the near future.

In this study, COVID-19 is targeted to identify the outbreak's impact on vaccination rates in Turkey.

\section{Material and Method}

Our study is a simple descriptive cross-sectional study. The data of the study were evaluated retrospectively. In the Marmara region, the health units that are obliged to follow up and vaccinate at least 50 or more children in the $0-2$ age group were reached.

The units who agreed to participate and share data were listed, and one of every ten units was selected randomly, and the data of eleven family Medicine Units were included in the study. All statistical analyzes in the study were performed using SPSS 24.0 software (IBM SPSS, Chicago, IL, USA). Whether continuous variables are suitable for normal distribution was confirmed by the Kolmogorov-Smirnov Test. The differences between the groups in terms of continuous variables were performed with Paired-Samples T-Test analysis. The results were evaluated within the $95 \%$ confidence interval, and p <0.05 was considered as the significance level.

Local ethics committee approval was received for the study on İstanbul Gelisim University Ethical Committee with approval number of (2020/14- 20.05.2020).

\section{Results}

A total of 5 family practice centers, 11 family practice units data were involved in the study. A total of 37.966 individuals were evaluated. The total number of children between 0-2 years in these centers was 1425. While the mean number of outpatient clinics was $1377.55 \pm 785.48$ in March 2019, this rate was determined as 1023.64 \pm 452.32 in March 2020. (p: 0.016) The mean number of outpatient clinics in April 2019 was 1235.18 \pm 703.38, which decreased to $577.55 \pm 320.58$ in April 2020. This decrease was statistically significant (p: 0.002); Chart 1 shows a detailed comparison of the number of applications to polyclinics. 
Chart 1: Number of outpatient clinics

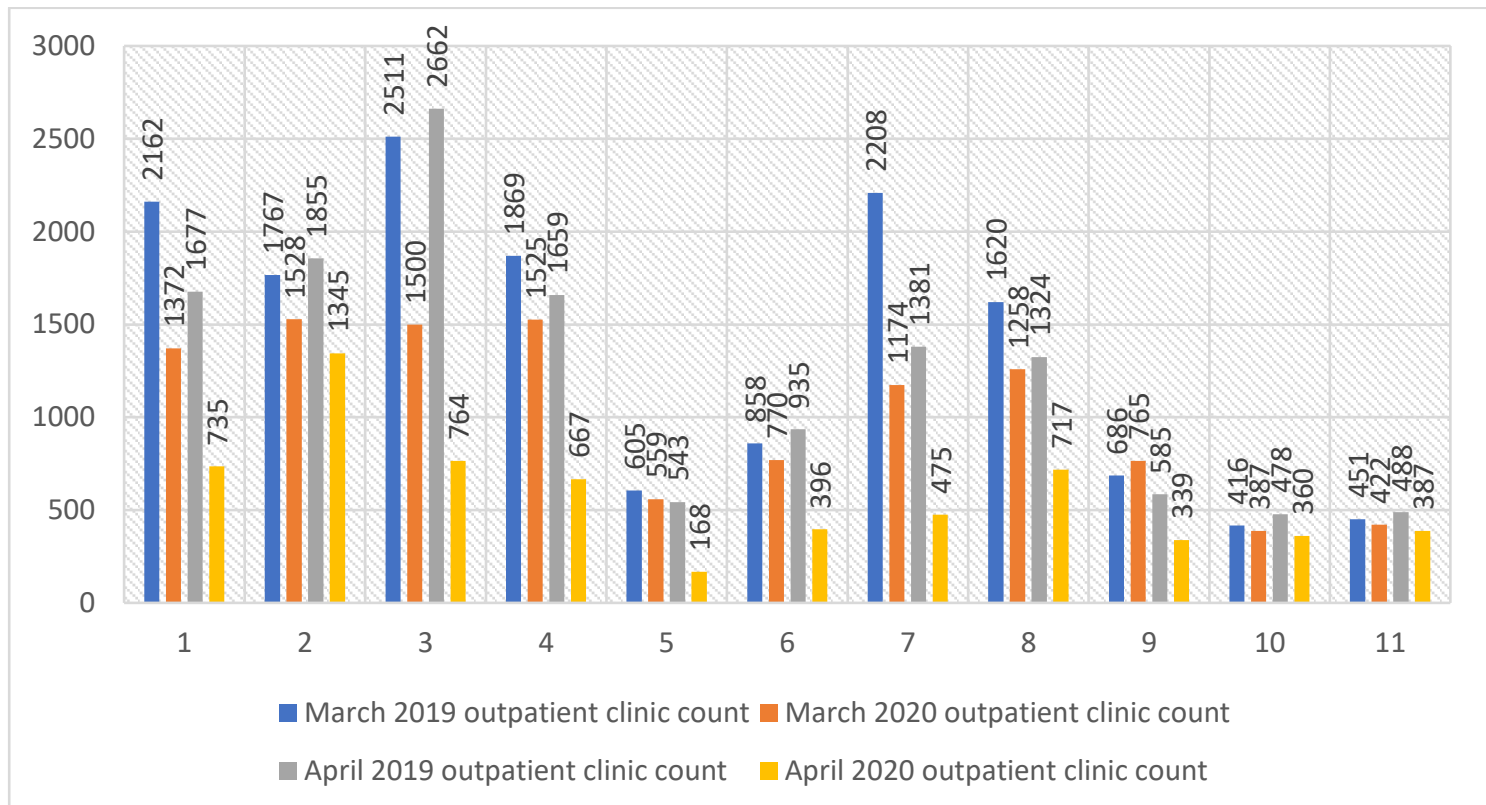

While the necessary mean number of vaccinations performed in these centers in March 2019 was $65,82 \pm 33,45$, the actual mean number of the vaccinations was $65,36 \pm 32,83$. The rate of vaccination during this period was $99,54 \pm 0,85 \%$, while the vaccination rate in April 2019 was 99,90 $\pm 0,30 \%$. The mean rate of vaccination in March 2020 was 97,7 $\pm 2,89 \%$; this rate was 96,30 $\pm 5,93 \%$ in April. When we compare 2019 and 2020, vaccination rates decreased slightly in March and April. However, no statistically significant difference was found. (Respectively p: 0,057 and 0,074) A detailed examination of the vaccination rates is shown in Table 1. Among the vaccinations that could not be performed in 2020, only three families have declared a signed statement that they will not receive vaccinations corresponding to the vaccination period of their children due to the coronavirus pandemic. The rest were the families that have already denied vaccination for different reasons. 
Table 1: Comparison of vaccination ratios

\begin{tabular}{|c|c|c|c|c|c|c|}
\hline \multicolumn{7}{|c|}{ Vaccination Ratio (\%) } \\
\hline \multicolumn{4}{|c|}{ March } & \multicolumn{3}{|c|}{ April } \\
\hline & 2019 & 2020 & $\mathrm{p}$ & 2019 & 2020 & $\mathrm{p}$ \\
\hline 1 & 100,00 & 100,00 & \multirow{11}{*}{0,057} & 100,00 & 100,00 & \multirow{11}{*}{0,074} \\
\hline 2 & 100,00 & 100,00 & & 100,00 & 100,00 & \\
\hline 3 & 100,00 & 97,40 & & 100,00 & 100,00 & \\
\hline 4 & 100,00 & 100,00 & & 100,00 & 100,00 & \\
\hline 5 & 97,50 & 96,60 & & 100,00 & 91,30 & \\
\hline 6 & 100,00 & 98,70 & & 100,00 & 100,00 & \\
\hline 7 & 99,00 & 91,30 & & 100,00 & 97,40 & \\
\hline 8 & 98,50 & 100,00 & & 100,00 & 80,80 & \\
\hline 9 & 100,00 & 100,00 & & 100,00 & 94,40 & \\
\hline 10 & 100,00 & 94,10 & & 100,00 & 100,00 & \\
\hline 11 & 100,00 & 96,80 & & 99,00 & 95,80 & \\
\hline
\end{tabular}

\section{Discussion}

Most of the therapeutic options available during the management of Covid - 19 are based on previous experience gained through Severe Acute Respiratory Syndrome (SARS) and Middle East Respiratory Syndrome (MERS-CoV) outbreaks. Researchers are working on effective and appropriate vaccines and treatment options to control deadly COVID-19, both of which have not been discovered yet. That is why we have to rely only on strict but preventive sanctions that minimize risk in the present moment ${ }^{6}$.

The concept of vaccine rejection started in the $90 \mathrm{~s}$ in the world as of 2010 in our country. In 2012, the Vaccine Hesitancy Working Group was established by the WHO to investigate vaccine rejection7. In the report prepared as a result of the study established by this group, two different concepts were accepted as "vaccine hesitation" and "vaccine rejection." Vaccine hesitation is defined as a delay in accepting the vaccine or rejecting it despite being vaccinated, which may be against one or more vaccines, while vaccine rejection is defined as the rejection of all vaccines and not having vaccines administered ${ }^{8}$. According to the study conducted by Jarett et al., 9 if we do not consider vaccine 
accessibility as a problem, trust concerns about vaccines with the guidance of religious and philosophical activist people are the main problem in the rejection of vaccines. From 2016 to 2018, a decrease of $2 \%$ was detected in Turkey ${ }^{10}$. The most critical allegation regarding vaccine charges in studies conducted abroad is "Vaccines contain mercury, aluminum, ether, antibiotics, and many chemicals, and they cause autism and similar diseases" 7,11 .

As of 2007, in Turkey, vaccination rates for each antigen have increased to over 95\%. The reasons for not having such a rate previously can be connected to the insufficiency of the data-record system, the geographical location and the variability of climate conditions, the need to regulate law-based measures, and the absence of negative financial incentives for healthcare providers7. Such that, in a study conducted in Şanlıurfa in 2004, the rate of never being vaccinated was found to be $28,4 \%$. The subgroups of this ratio revealed the following reasons; unable to get vaccinated due to temporary agricultural work (27\%), underestimating the vaccination (21\%), thinking that the vaccine is harmful (21\%), the idea that the vaccine may be administered against a fee $(12,1 \%)$. The participants who were not vaccinated in this study expressed that the negative information they gained about vaccines was through their neighbors and relatives ${ }^{12}$.

There is no legal regulation against vaccine rejection in Turkey. The varying rate of reported vaccination rejection in Turkey shows that the number of vaccination rejection is not yet a large part of the society, and it is early to comment on this issue ${ }^{13}$. According to the study of Dubé et al.14, the trust problem in vaccines was among the reasons suggested by anti-vaccine families in developed countries. Bond and Nolan ${ }^{15}$ reported that the severity of the perceived disease in mothers contributed to vaccination. Again, in our country, in the study of Çıklar and Güner ${ }^{16}$, almost all of the mothers stated that vaccines are necessary and their child's vaccines are complete. For the question about why the vaccine is necessary, "protects against disease" and "creates resistance against microbes" answers were mostly given, and this situation was interpreted as mothers' revealing of trust in vaccination and belief in protection.

Due to the pandemic, there may a problem about routine immunization activities due to both COVID-19 related burden on the health system and decreased demand for vaccination because of social distancing requirements or community reluctance. Guiding 
principles and considerations to support countries in their decision-making regarding provision of immunization services during the COVID-19 pandemic and is endorsed by the WHO's Strategic Advisory Group of Experts on Immunization. If provision of immunization services is affected by COVID-19, countries will need to design strategies for catch-up vaccination for the period post COVID-19 outbreak ${ }^{17}$.

Preventing Vaccine-Preventable Diseases (VPD) outbreak not only saves lives but requires fewer resources than responding to the outbreak and helps reduce burden on a health system already strained by the COVID-19 pandemic. WHO says both newborn vaccination programmes and adult vaccinations (especially pneumococcal, influenza, or pertussis vaccination programmes) should continue as planned during the COVID-19 pandemics. They also say ongoing surveillance for other VPDs should continue as much as possible ${ }^{18}$.

WHO announced that Turkey was free from polio in 2002 and maternal and neonatal tetanus in2009, thanks to the effective vaccination program. There is a marked decrease in the incidence of other diseases. Although the vaccination rate of measles only increased, some increase in its prevalence was seen in 2013, and this rate was decreased again with additional vaccination ${ }^{19}$.

International Health Regulations Emergency Committee remains gravely concerned by the significant increase in Wild poliovirus type 1 (WPV1) cases globally in 2019 and 2020, with 175 cases in 2019 compared to 33 in 2018, and already 32 cases as at 17 March $2020^{19} .18$ of these cases were from Africa; Benin (1), Democratic Republic of the Congo (2), Ethiopia (5), Ghana (5) and Togo (5) reported cases $^{20}$.

The Committee is extremely concerned about the impact of the COVID-19 pandemic on the risk of heightened transmission of polio and consequently the potential for international spread and significant reversal of polio eradication. The Committee recognizes the concerns regarding the lengthy duration of the polio Public Health Emergencies Of International Concern (PHEIC), but concludes that the current situation is extraordinary, with clear ongoing risk of international spread and ongoing need for coordinated international response The Global Polio Eradication Initiative (GPEI) functions continue, polio programme personnel and staff are kept safe, and to plan for a fast and effective resumption of polio eradication activities including supplementary 
immunization activities as soon as the public health situation with COVID-19 allows. This is relevant not only to polio, but to all other vaccine preventable diseases particularly measles ${ }^{21}$.

According to the 2017 data of the European Center for Disease Control and Prevention (ECDC), it has been determined that the number of measles cases in Europe is approximately three times of 2016, and $87 \%$ of the diagnosed cases refused to be vaccinated. In this measles outbreak in Europe due to vaccination rejection, 35 patients were reported $\operatorname{dead}^{22}$. According to WHO data, around 20 million children - more than 1 in 10 - worldwide have missed life-saving vaccines such as measles, diphtheria, and tetanus in 2018. The majority of these children still live in countries with fragile health systems and further limit their access to primary health care when they get sick. Measles remains an ever-present threat, especially when vaccination rates decrease. Current estimates indicate that the number of cases of measles reported for 2019 will be at least $8000^{23}$.

The impact of the pandemic on pediatric vaccination in the United States: Vaccines for Children Program (VFC) provider order data from Centers for Disease Control and Prevention (CDC)'s Vaccine Tracking System (VTC) and Vaccine Safety Datalink (VSD) vaccine administration data were analyzed. VFC-funded vaccines ordered by health care providers at weekly intervals during two periods (January 7, 2019-April 21, 2019 [period 1] and January 6, 2020-April 19, 2020 [period 2]) were viewed, VTC data indicate a notable decrease in orders for VFC-funded, the Advisory Committee on Immunization Practices (ACIP) recommended noninfluenza childhood vaccines and for measlescontaining vaccines during period 2 compared with period 1 . When social distancing rules are relaxed, it will be inevitable to encounter diseases such as measles in unvaccinated children ${ }^{24}$.

During an epidemic, especially family physicians and emergency department specialists will face large patient mass. In the COVID-19 pandemic, in March 2020, although the number of outpatient clinics involved in the study was unaffected, serious decreases were observed in April 2020 which can be explained with the identification of the first COVID19 cases by March 11, 2020, and the public acceptance of 'home insulation' awareness ${ }^{23}$. However, despite these decreases, all units completed almost all of their vaccination 
applications within two months. Monthly salaries of doctors and nurses in the Family Health Center in Turkey increase or decrease according to the performance system applied, which depends on the follow-up rates in their units. One of these follow-up rates is the number of children to be vaccinated. If the doctor and nurse concerned do not vaccinate the child during these periods and do not declare a medically or legally valid written reason for not applying the vaccination, a deduction is made from the monthly salary. This system was not even temporarily removed due to the pandemic and vaccination of children was continued. For those who are under some pandemic quarantine and cannot bring their children for vaccination, even vaccination at home has been brought up by family physicians.

All these are indications of the importance that healthcare professionals in Turkey attach importance to the immunization service. The chance of easy access to healthcare and the fact that people communicate with their primary care staff due to chronic diseases and periodic examinations and follow-ups contribute to the formation of a sense of trust. The follow-ups in family health centers start with the pregnancy of the mothers and continue until the children are five years old. Furthermore, our vaccination rates between $0-2$ years of age prove this feeling of trust. A financial sanction may be a positive justification for the healthcare provider, but this is not a concern for the family who will not be vaccinated. Of course, almost all of the patients that Family Physicians followed up in all centers for years were hesitant about bringing their children to institutions for vaccination during this period. However, Family Physicians have changed the provided daily appointment system to an hourly system for vaccination. Especially with the initiation of triage system during pandemics, families were informed both about the virüs that had no vaccine or specific treatment worldwide and the importance of vaccines.

\section{Conclusion}

As a result, the vaccine is still the only power we have to continue to keep the doors closed to new outbreaks. The best proof of this is the anxiety experienced with COVID-19 pandemic, and comfort against diseases that can be prevented with vaccines and even eradicated formerly. To prevent vaccination rates from decreasing even in the pandemic cases detected in our study, especially primary health care professionals will continue to work with devotion. For our three families who declared rejection for vaccination due to 
coronavirus pandemics, the relevant units are aiming to complete the vaccinations after the epidemic. We consider this situation not as vaccine rejection, but as vaccine hesitation.

The limitation of our study is the number of Family Practice Units reached for the sample. Therefore, our results do not reflect the situation of the whole society. With the addition of more unit information, we may be able to achieve a higher number of COVID19 induced vaccine rejection, but we do not think that this number will affect the overall vaccination percentage. Because primary health care providers in our country have always defended the importance of vaccines in keeping human health safe, informed their patients, and will continue to do so.

\section{Declarations:}

All authors see the final version of the manuscript and give consent for publication. The authors declare no conflict of interest. No financial resources were used in this study.

\section{REFERENCES}

1. Republic of Turkey Ministry of Health. History of the vaccine in Turkey (Ankara). Available from: https://asi.saglik.gov.tr/genel-bilgiler/33-așınıntarihçesi.html. Accessed May 102020.

2. World Health Organization (Copenhagen). Health Topics, Immunization. Available from: https://www.who.int/topics/immunization/en/. Accessed April 102020.

3. Turkish Medical Association, Vaccination Guide for Primary Health Care Professionals 2019 (Ankara). Available from: https://www.ttb.org.tr/kutuphane/asi rehberi2.pdf. Accessed April 302020.

4. World Health Organization (Copenhagen). Immunization, Vaccines and Biologicals - Release of the Global Vaccine Action Plan Review and Lessons Learned Report. Available from: https://www.who.int/immunization/global vaccine action plan/en/. Accessed May 62020. 
5. World Health Organization (Copenhagen). Coronavirus Disease (COVID -19) Situation Reports. Available from:

https://www.who.int/emergencies/diseases/novel-coronavirus-2019/situationreports/. Accessed May 152020.

6. Dhama K, Sharun K, Tiwari R, et al. COVID-19, an emerging coronavirus infection: advances and prospects in designing and developing vaccines, immunotherapeutics, and therapeutics. Hum Vaccin Immunother. 2020;18:1-7.

7. World Health Organization (Copenhagen). Immunization, Vaccines and Biologicals. Guiding Principles for Immunization Activities During the COVID19 Pandemic. Available from:

https://www.who.int/immunization/policy/sage/en/. Accessed March 292020.

8. Larsona HJ, Jarrett C, Schulz WS, et al. Measuring vaccine hesitancy: The development of a survey tool. Vaccine. 2015;33(34):4165-4175.

9. Jarrett C, Wilson R, O’Leary M, et al. Vaccine hesitancy. strategies for addressing vaccine hesitancy - a systematic review. Vaccine. 2015;33:41804190.

10. Özceylan G, Toprak D, Esen ES. Vaccine rejection and hessitation in Turkey. Hum Vaccin Immunother. 2020;16(5):1034-1039.

11. Hausman BL, Ghebremichael M, Hayek P, et al. Poisonous, filthy, loathsome, damnable stuff': the rhetorical ecology of vaccination concern. Yale J BiolMed. 2014;87:403-416.

12. Kurçer MA, Şimşek Z, Solmaz A, et al. Vaccination rates and problem in vaccination in 0-2 years old children and pregnant women in Sanliurfa Harrankapı Health Center Region. Harran Üniv Tıp Fak Derg. 2005;2(2):1015 .

13. Bozkurt HB. An overview of vaccine rejection and review of literature. Kafkas. $J$ Med Sci. 2018;8(1):71-76. doi:10.5505/kjms.2018.12754. 
14. Dubé E, Gagnon D, MacDonald N, et al. Underlying factors impacting vaccine hesitancy in high incomecountries: a review of qualitative studies. ExpertRev Vaccines. 2018;17(11):989-1004. doi:10.1080/14760584.2018.1541406.

15. Bond L, Nolan T, Pattison P, et al. Vaccine preventable diseases and immunisations: a qualitative study of mothers' perceptions of severity, susceptibility, benefits and barriers Aust N Z J Public Health. 1998;22(4):441-6.

16. Çıklar S, Güner PD. Knowledge, behavior and attitude of mother's about childhood immunization and reasons of vaccination rejection and hesitancy: a study of mixed methodology. AnkaraMed J. 2020;(1):180-195.

17. World Health Organization (Copenhagen). Guiding Principles for Immunization Activities During the COVID-19 Pandemic. Available from: https://apps.who.int/iris/bitstream/handle/10665/331590/WHO-2019-nCoVimmunization services-2020.1-eng.pdf. Accessed May 202020.

18. World Health Organization (Copenhagen). Immunization in the Context of COVID-19 Pandemic. Frequently Asked Questions. Available from: https://apps.who.int/iris/handle/10665/331818. Accessed May 202020.

19. World Health Organization (Copenhagen). Measles. Available from: https://www.who.int/news-room/facts-in-pictures/detail/measles. Accessed April 212020.

20. Outbreak News Today (United States). Polio: Five Additional WPV1 Cases Reported in Pakistan and Afghanistan. Available from: http://outbreaknewstoday.com/polio-five-additional-wpv1-casesreported-in-pakistan-and-afghanistan-11265/. Accessed May 202020.

21. World Health Organization. Statement of the Twenty-Fourth IHR Emergency Committee. Available from: https://www.who.int/news-room/detail/o8-042020-statement-of-the-twenty-fourth-ihr-emergency-committee. Accessed May 202020.

22. European Center for Disease Control and Prevention. Measles and Rubella Surveillance for 2017. Available from: 
https://www.ecdc.europa.eu/en/publications-data/annual-measles-andrubella-monitoring-report-2017 Accessed May 202002.

23. Republic of Turkey Ministry of Health. Current Situation in Turkey, Turkish Public Health Institution. Available from: https://covid19.saglik.gov.tr/. Accessed May 92020.

24. Centers for Disease Control and Prevention. Morbidity and Mortality Weekly Report (MMWR). Available from:

https://www.cdc.gov/mmwr/volumes/69/wr/mm6919e2.htm. Accessed May 202020. 